\section{Geografia turyzmu w Akademii Świętokrzyskiej \\ im. Jana Kochanowskiego w Kielcach Zakład Dydaktyki Geografii \\ i Krajoznawstwa}

W Instytucie Geografii Akademii Świętokrzyskiej im. Jana Kochanowskiego w Kielcach geografia turyzmu weszła na stałe do problematyki badań od 1993 r. Utworzono wówczas istniejący do dzisiaj Zakład Dydaktyki Geografii i Krajoznawstwa. Kierował nim dr Ignacy Janowski, który do 2005 r. zajmował się waloryzacją turystyczną regionu świętokrzyskiego i badaniami ruchu turystycznego w województwie świętokrzyskim. Obecnie kierownikiem Zakładu jest dr hab. Wacław Cabaj, prowadzący badania w dziedzinie geoturystyki i geografii turystycznej. Pracujący w Zakładzie od 2005 r. dr Cezary Jastrzębski zajmuje się dziejami turystyki, krajoznawstwem oraz geografią turyzmu w widłach Wisły i Pilicy.

\section{Geography of tourism at the Jan Kochanowski Świętokrzyska Akademia in Kielce The Department of Geography, Landscape and the Countryside}

In the Institute of Geography at the Jan Kochanowski Swietokrzyska Akademia in Kielce the geography of tourism has been a permanent issue of research since 1993. The Department of Geography, Landscape and the Countryside was founded then. Until $2005 \mathrm{Dr}$ Ignacy Janowski was in charge of the Department and he researched the tourism value of the Swiętokrzyski Region and tourist activity in the Swiettokrzyskie Województwo. The present Head of Department is Dr hab. Waclaw Cabaj, who researches geotourism and the geography of tourism. Dr Cezary Jastrzęski, who has been working in the Department since 2005, deals with the history of tourism, appreciation of the landscape and the countryside' and the geography of tourism in the area between the Vistula and Pilica rivers.

Cezary Jastrzębski 